\title{
IMPACT OF DIGITALIZATION ON LEGAL REGULATION: FORMATION OF NEW LEGAL PRACTICES
}

\author{
1Maya Livson \\ ${ }^{2}$ Sergey Eshtokin \\ ${ }^{3}$ Vitalii Vasyukov \\ ${ }^{4}$ Elena Yudina \\ ${ }^{5}$ Andrey Baybarin \\ ${ }^{6}$ Svetlana Pivneva
}

\section{ABSTRACT}

Objective: The objective of the research is to examine the impact of digital technologies introduced into law on the formation of new legal practices.

Method: The authors used a mixed methodological strategy. The main research method is the dialectical method. Regulatory documents of Russia and foreign countries were chosen as the information basis for the research.

Results: The article examines the Russian and international experience of organizing legal activities using innovative digital technologies that allow organizing the effective work of a lawyer in legal support of economic and other regulated activities, preparing for the adoption of regulatory legal acts, optimizing legal proceedings. The authors assess the possibilities and prospects of using intelligent digital systems in the practice of a professional lawyer, law-making, the use of artificial intelligence in the field of justice, as well as the risks that such use may carry.

Conclusions: The terms of preparation of regulatory legal acts are reduced in digital content, their quality is improved, the procedural form and other types of law enforcement are optimized. However, the total and uncontrolled use of digital technologies in law can lead to a violation of human rights. The purpose of the author of the presented article was to study the innovations used in modern jurisprudence, to determine their capabilities and limitations in use. Authors conclude that the use of digital technologies in law-making and law enforcement should be based on strict observance of basic human and civil rights.

Keywords: Digital technologies. Law-making. Law enforcement. Human rights.

Received: $11 / 01 / 2021$

Accepted: 25/04/2021

DOI: https://doi.org/10.37497/revcampojur.v9i2.749

${ }^{1}$ Moscow Polytechnic University, (Rússia). E-mail: Orcid id: maya.livson@ mail.ru https://orcid.org/0000-0003$\underline{0713-0417}$

${ }^{2}$ Market Economy Institute of Russian Academy of Sciences (MEI RAS), (Rússia). E-mail: S.V.Eshtokin@yandex.ru Orcid id: https://orcid.org/0000-0002-2939-2234

${ }^{3}$ Orel Law Institute of the Ministry of internal Affairs of Russia named after V. V. Lukyanov, (Rússia). E-mail: vvf0109@yandex.ru Orcid id : https://orcid.org/0000-0003-0743-5616

${ }^{4}$ Russian State University of Tourism and Service, (Rússia). E-mail: itbrmat@mail.ru Orcid id: https://orcid.org/0000-0001-6006-7678

${ }^{5}$ Southwest Minnesota State University - SMSU, (Minnesota). E-mail: andrewbaybarin@ gmail.com Orcid id:https://orcid.org/0000-0001-9183-3101

${ }^{6}$ Russian State Social University; Moscow Polytechnic University, (Rússia). E-mail: tlt-swetlana@yandex.ru Orcid id: https://orcid.org/0000-0003-2288-9915 


\section{IMPACTO DA DIGITALIZAÇÃO NA REGULAÇÃO JURÍDICA: FORMAÇÃO DE NOVAS PRÁTICAS JURÍDICAS}

\section{RESUMO}

Objetivo: O objetivo da pesquisa é examinar o impacto das tecnologias digitais introduzidas no direito na formação de novas práticas jurídicas.

Método: Os autores utilizaram uma estratégia metodológica mista. O principal método de pesquisa é o método dialético. Documentos regulatórios da Rússia e de países estrangeiros foram escolhidos como base de informação para a pesquisa.

Resultados: $\mathrm{O}$ artigo examina a experiência russa e internacional de organização de atividades jurídicas usando tecnologias digitais inovadoras que permitem organizar o trabalho efetivo de um advogado no apoio jurídico de atividades econômicas e outras reguladas, preparando-se para a adoção de atos jurídicos regulatórios, otimizando os processos judiciais. Os autores avaliam as possibilidades e perspectivas do uso de sistemas digitais inteligentes na prática de um advogado profissional, legislador, o uso de inteligência artificial no campo da justiça, bem como os riscos que tal uso pode acarretar.

Conclusões: Os prazos de elaboração dos atos normativos legais são reduzidos nos conteúdos digitais, sua qualidade é melhorada, a forma processual e outros tipos de aplicação da lei são otimizados. No entanto, o uso total e descontrolado das tecnologias digitais no direito pode levar a uma violação dos direitos humanos. O objetivo do autor do artigo apresentado foi estudar as inovações utilizadas na jurisprudência moderna, para determinar suas capacidades e limitações de uso. Os autores concluem que o uso de tecnologias digitais na elaboração e aplicação da lei deve ser baseado na estrita observância dos direitos humanos e civis básicos.

Palavras-chave: Tecnologias digitais. Legislação. Aplicação da lei. Direitos humanos.

\section{INTRODUCTION}

Digitalization is one of the most dynamic global trends in the 21 st century. Its total penetration into the life of modern society has formed a new reality, the features of which are the use of digital technologies in all spheres of human activity, which, in turn, contributes to the active development of human capital, modernization of the economy, the transformation of state and public institutions and, accordingly, improvement of the conditions of everyday life of citizens (Kirillova et al., 2021). The traditional conditions of interpersonal and social interaction (before the era of the introduction of the Internet into everyday life) are gradually being replaced, a new communicative space is being created (Sarpekov, 2020).

The development of modern means of communication and the development of their potential is causing serious changes in the mechanisms of education and the operation of law (Ramazanov et al., 2021). Designed to regulate public relations, the law somehow falls under 
the regulatory influence of new technologies. Digital content carries undeniable and unconditional advantages. Many legal processes proceed at higher speeds in the aspect of space and time compression (Zavyalov et al., 2021). The former legal branches and institutions are being transformed, new information and legal relations are being formed. Although the legal policy is already virtually immersed in a digital format, at the same time it is designed to develop means of adapting the law itself to such changes. In this regard, it is relevant to consider the main areas of application of digital systems in various fields of jurisprudence.

The interest in the technologization of legal activity is predictably growing in the conditions of digitalization. The authors consider it important to note several works, namely, such aspects of the digitalization of law as the ratio of legal values and digital legal technologies (Lang, 2021), the impact of digitalization on the emergence of new types of legal relations (Sarpekov, 2020), features of the use of digital technologies in lawmaking (Chervonyuk, 2021a, 2021b). The presence of many works on the problems of digitalization in law, including those published under the aegis of reputable legal institutions, does not yet allow us to fully assess the possibilities of using digital legal technologies in general, and in particular, containing elements of artificial intelligence, in the main areas of legal activity and the boundaries of their application in law. An attempt at such an assessment is the goal of this work.

In our article, we proceed that in the legal sphere, introduction of digital technologies has some advantages that help practicing lawyers in lawmaking and law enforcement. But even the most advanced digital technologies will be able to perform only a technological function designed to simplify the workflow in legal activities.

\section{MATERIALS AND METHODS}

The dialectical method of cognition of reality was chosen as the main research method for this work, which allows studying the process of digitalization of legal activity in its dynamics. The method of analysis and synthesis allowed characterizing the main directions, tasks, and goals of digitalization of legal activity; the comparative-legal method helped to consider similar processes taking place in foreign legal systems, to compare the approaches that have developed in Russia and foreign countries to the organization and regulation of the process of introducing digital elements into law-making and law enforcement activities. In the study, special attention was paid to the formal legal method used to describe and explain the essence of the basic principles of law and fundamental human rights, which are at increased risk in the conditions of digitalization. The information basis for proving the hypothesis was made up of 
regulatory documents of Russia and foreign countries, previously conducted and published studies of scholars on the stated problems, statistical information posted on websites, opinions of authoritative law enforcement officers. The selection of information sources was carried out according to the criteria of compliance of the title of the material and the text with the topic of this study.

\section{RESULTS}

Whole new industries regularly appear in the conditions of the so-called "fourth industrial revolution", when there is an almost annual change of technologies and business models in traditional sectors of the economy, the demand for updated law, and the rationalization of legal activity has increased immeasurably (Chervonyuk, 2017). From this point of view, mastering technical and legal tools (legal techniques) and their effective application (legal technologies) is not only a necessary condition for the highly productive work of a lawyer but also one of his/her most important qualifications as a specialist.

The movement in this direction was already clearly marked in the early 2000s when LawTech (The Law Society, 2021) - platforms designed for practicing lawyers were established in the United States, and then, when together with the promotion of online legal consultations and automated document creation services, other startups, the now world-famous LegalTech (FRIES, 2017) appeared as a form of automation of various legal services and processes through the introduction of modern information technologies. It is aimed at radically changing the way services are provided, and in some cases, at trying to replace lawyers with artificial intelligence. Examples of such attempts are the project of the Skolkovo Foundation "LegalTech Map of Russia", the creators of which are going not only to take an inventory of existing robots but also to develop certain rules in the field of the digital economy with the participation of experts in the future, to propose principles of legislative regulation of robotics (Mitin, 2019; Vinichenko, Melnichuk, Karácsony, 2020).

Another area of LegalTech is contract work, for example, the FreshDoc project, with which it is possible to prepare a draft contract. The builder of such documents offers more than 1500 templates. This is a personal robot lawyer. There is also a "Video agreement" application, which records the agreement between the parties on video (makes a video protocol of the meeting). The preparation of a video contract can be carried out from anywhere in the world where there is an Internet connection, which eliminates the distortion of the original 
agreements. Nevertheless, the video agreement shall be duplicated on paper in transactions requiring state registration. The Legal Space should not go unmentioned - a "marketplace" for lawyers, where they could offer their services in certain areas of law to a wider audience. This is essentially an electronic trading platform, and it could be called a "commodity aggregator" at the legislative level. This site simultaneously performs three functions: it provides an opportunity to get acquainted with the seller's (contractor's) offer to conclude a purchase and sale agreement (a contract for the provision of paid services); to conclude such an agreement with the seller (contractor); to make an advance payment for the specified goods (services) by non-cash payment. Pravoved.Ru - another "marketplace" undoubtedly helps ordinary users who do not work in the field of law and at the same time the place of earnings of lawyers who offer their services after an online user request (Mitin, 2019; Kirillova, et al., 2020).

Digital technologies make it possible to automate the processes of rule-making, improve their quality, and reduce the time spent on the development of laws and other regulatory legal acts.

The most important value is attached to the formation of a digital legal language in the automation of rule-making. The introduction of mechanisms for the formation and use of machine-readable norms is one of the tasks of the "Digital Economy of the Russian Federation" national program (The program "Digital Economy of the Russian Federation", 2017; Volodina; Gavrilov, 2020).

The Simplawyer company offers three main scenarios for digitalization of rule-making in its concept of law automation:

1) creation of a legal programming language;

2) automation of legislation in natural language (in simple terms, the use of tags by keywords in regulatory enactments);

3) the symbiosis of the two proposed mechanisms, involving the parallel use of natural language expression of norms with parallel coding for automation using manual debugging of algorithms (Zikeev, 2020).

The formation of a digital normative language is a prerequisite for the transition to automated lawmaking. Experts of the Skolkovo Foundation note that the meta-markup of documents in natural language is very helpful for specialists working with documents, but even in this case, one cannot fully refer to the automation of law. To implement the mechanism of self-fulfillment of norms, they shall be machine-readable. Existing legal programming languages allow performing algorithms of actions and check compliance with simple conditions (Zikeev, 2020; Turkin, et al., 2019). 
The special importance of judicial protection in the mechanism of ensuring rights and freedoms determines the problems of using innovations in the field of justice. At the moment, the judicial system already incorporates some elements of Legal Tech, however, today it is only a tool that simplifies the work of a judge, but by no means an intellectually self-developing system. Thus, all judges in Singapore are provided with the opportunity to use the following online systems to facilitate the adoption of judicial decisions: LawNetLegalWorkbench (intelligent search through legal databases); JODB (a database containing judicial working documents and collections); SINGS (a system of sentencing rules that provides sentencing criteria and information); IMPRESS (a system that records decisions of the Supreme Court and local courts (Shulgin, 2019).

Predictive justice is also a promising direction of digitalization of legal proceedings. It is a case of obtaining algorithms for making decisions on disputes based on court decisions uploaded to the database, the circumstances of the requested case, the characteristics of the parties (Konstantinov, 2020). According to research data, such technologies can repeat the decisions of the US Supreme Court in $70 \%$ of cases (Katz, Bommarito, Blackman, 2017) and the decisions of the European Court of Human Rights in 79\% of cases (Aletras et al., 2017). There are categories of cases for the solution of which it is possible to involve intelligent systems and it is unwise to spend a much more expensive human resource. These are the socalled "indisputable cases", for which the judge checks only formal data. For example, a loan delay, where the parties agree with the plot, and the solution is obvious (Miroshnichenko, Safin, Khokhlova, 2019).

Table 1: The main directions of using digital services in law

\begin{tabular}{|l|l|l|}
\hline Direction & General characteristics of the service & $\begin{array}{l}\text { Service name and country of } \\
\text { use (examples) }\end{array}$ \\
\hline $\begin{array}{l}\text { General support of } \\
\text { legal services }\end{array}$ & $\begin{array}{l}\text { Automation of various processes, improving } \\
\text { the quality of services, reducing costs }\end{array}$ & $\begin{array}{l}\text { Pravorurobot, FreshDoc } \\
\text { (Russia), Lexoo (USA) }\end{array}$ \\
\hline $\begin{array}{l}\text { Development of } \\
\text { the electronic } \\
\text { justice system }\end{array}$ & $\begin{array}{l}\text { Generation of court decisions, control of the } \\
\text { judicial practice }\end{array}$ & $\begin{array}{l}\text { LawNetLegalWorkbench, } \\
\text { IMPRESS (Singapore), } \\
\text { UniCourt (USA), casebook } \\
\text { (Russia) }\end{array}$ \\
\hline Rulemaking & $\begin{array}{l}\text { Analysis of the state of the regulatory } \\
\text { framework, development of a draft } \\
\text { regulatory act and accompanying } \\
\text { documents, examination of documents for } \\
\text { compliance with legislation and corruption }\end{array}$ & $\begin{array}{l}\text { ASOZD (Russia), Expertisze } \\
\text { (Netherlands), }\end{array}$ \\
(USA)
\end{tabular}




\section{DISCUSSION}

In our opinion, one of the most important problems that shall be solved by widely introducing digital technologies into the legal sphere is the problem of determining the limits of the participation of these technologies in law-making and law enforcement activities. There is a certain skepticism about rule-making with the participation of digital technologies on the part of certain representatives of the legal establishment - well-known law enforcement officers, whose authority is not in doubt. At this point, doubts arise about the possibilities of artificial intelligence in comparing legal prescriptions with forecasts and social models of the impact of legal norms on public relations. Chairman of the Constitutional Court of the Russian Federation V.D. Zorkin noted that the proposal of specialists to "pack" laws into program code to ensure the harmony, certainty, and unambiguity of the content of normative acts seems fantastic to him (Zikeev, 2020).

The most acute discussions are held about the automation of justice. The main doubts are caused by the idea of the possibility of making procedural decisions using digital technologies containing elements of artificial intelligence (Gritsenko, Yaluner, 2020).

It seems to us that a strict separation of the spheres of human activity and automatic systems is possible and necessary when using artificial intelligence in the administration of justice. We fully agree with the problem highlighted by K. Mamak that the increasing similarity of robots with humans can lead to danger for humans and criminal prosecution of the robots themselves (Kamil, 2021). The robot's assessment of legal action in isolation from the assessment of the person who committed it can negatively affect the validity and fairness of such decisions and, in general, the state of protection of fundamental rights of the individual. In this regard, artificial intelligence cannot be allowed to make procedural decisions that are based on the assessment of personality (the so-called "human factor") and other subjective factors that do not have obvious logical relationships and, therefore, are not amenable to "machine processing". Therefore, it is necessary to join R.K. Sarpekov's proposal to use artificial intelligence elements exclusively for conducting operations that do not require certain qualifications (for example, selecting jurors from the main and additional lists, calculating procedural costs, simultaneous translation, keeping the minutes of the court session, remote interrogation, drawing up documents according to a template, giving consultations on the simplest legal issues that do not require legal assessment, searching and identifying suspicious persons from video images, etc.) (Sarpekov, 2020). 
Legislators, and especially law enforcement officers, as it seems obvious, need to take into account that the quintessence of law, its fundamental basis is human rights, his/her freedoms, the transformation of which inevitably (implicitly) entails changes in nature of the person himself/herself (Chervonyuk, 2020). Due to this fundamental significance, the circumstances and the limits of changes in the law, moreover, not only in its content but also in its form, are decisively predetermined by the human rights factor (Bondar, 2019). That is why it is the law, and not the factor of the inevitability of the arrival of digital technologies in it, that should "determine the socially justified corridor of human intrusion into the artificial world of new technologies" (Chervonyuk, 2020). In a special legal language, this means that such value orientations shall be confirmed in the text of the law and following the requirement of legal certainty (Kornev, 2020), and in addition, the space of freedom of both an individual and groups of people shall be specially guaranteed. Thus, it is obvious that in the conditions of the COVID19 pandemic, the widespread isolation regime and the mass digital pass system being introduced, as well as the use of a face recognition system to impose administrative fines to protect individual rights, it is important to recognize the right to geolocation protection, highlight it specifically in the personal data protection system and develop a set of clear legal norms for the protection of such rights (Ivanova, 2020). There is a large number of erroneous bringing to administrative responsibility (the number of appeals amounted to tens of thousands in 2020) (Melnik, 2021) in cases when technical tracking devices operating in automatic mode are "wrong", legal scholars S.A Pravkin, V.V. Smirnova (in connection with the development and adoption of a new Code of Administrative Offenses) indicate the need to legally relate new technologies with the basic principles of legal responsibility, presupposing that evidence must meet the criteria of relevance, admissibility, sufficiency, etc. (Pravkin, Smirnova, 2020). Thus, the person who implements digital technologies in the sphere of law enforcement, whatever he/she may be guided by, must, first of all, take into account the basic values (the essence of a specific right, freedom) to avoid the risk of conflicting with both common sense and the goals and objectives of legal regulation. A clear and complete list of such value orientations in the form of absolute prohibitions that do not allow for any exceptions, as well as the principles under which the introduction of innovation is permissible, should be established by law, thereby serving as a reliable barrier to unrestrained and excessive digitalization. This opinion is supported by several researchers (Lang, 2021; Chervonyuk, 2017) who believe that classical legal values are a determining factor in the implementation of certain elements of digitalization in legal activity. 
In our opinion, one of the positive examples of this is the first European Charter of Ethics on the Use of Artificial Intelligence in the Judiciary, adopted on December 4, 2018, by the European Commission for the Effectiveness of Justice (CEPEJ) of the Council of Europe (CEPEJ, 2018). The document defines the priority principles that should be observed in criminal proceedings when using artificial intelligence: the principle of respect for fundamental human rights and freedoms, the principle of non-discrimination of persons, the principle of quality and safety of processing court decisions and other databases, the principle of transparency (the procedure and features of application should be clear), impartiality and fairness, the principle of user control of systems (judicial officers should understand what the conclusions are based on and analyze them based on the circumstances of the case).

\section{CONCLUSION}

The research carried out in this work has shown that the introduction of digital elements in law-making and law enforcement activities has both positive and potentially dangerous consequences. With a huge number of advantages that allow quickly and efficiently drafting regulatory acts, coordinating them taking into account the interests of the state and society, registering, certifying, recording a variety of legally significant facts and events, there is still a risk of violation of the basic principles of law and fundamental human rights with the uncontrolled and total introduction of digital technologies into legal activity. To prevent such a violation, it is necessary to legally establish the limits of the use of digital technologies in legal activity, highlighting areas where decision-making affecting the rights and legitimate interests of an individual is carried out exclusively under the competence of authorized "living" persons, and not intelligent digital systems. Thus, the hypothesis of this study has been proved.

We see the direction of future research in the analysis of the features of the introduction of digital elements into legal activity in narrow areas: criminal procedural activity, civil procedural activity, notary, and other highly specialized types of legal activity.

\section{REFERENCES}

ALETRAS, N., TSARAPATSANIS, D., PREOȚIUC-PIETRO, D., LAMPOS, V. (2017). Predicting judicial decisions of the European Court of Human Rights: a Natural Language Processing perspective. PLoS ONE, 12. https://doi.org/10.7717/peerj-cs.93 
BONDAR, N.S. (2019). Informatsionno-tsifrovoe prostranstvo v konstitutsionnom izmerenii: iz praktiki Konstitutsionnogo Suda Rossiiskoi Federatsii [Information and digital space in the constitutional dimension: from the practice of the Constitutional Court of the Russian Federation]. Zhurnal rossiiskogo prava, 11, 28.

CEPEJ. (2018). European Ethical Charter on the use of artificial intelligence in judicial systems. Available from: https://rm.coe.int/ethical-charter-en-for\%20publication-4-december2018/16808f699c Accessed: 29 Apr. 2021.

CHERVONYUK, V.I. (2020). Metodologiya podgotovki nauchnogo issledovaniya v yuridicheskoi otrasli nauki [Methodology for the preparation of scientific research in the legal branch of science]. Moscow: The Vladimir Kikot Moscow University of the Ministry of Internal Affairs of Russia.

CHERVONYUK, V.I. (2020). Predmet (predmetnye oblasti) i normativnaya struktura konstitutsionnogo prava $\mathrm{v}$ pravovom diskurse [Subject (subject areas) and normative structure of constitutional law in legal discourse]. Gosudarstvo i pravo, 2, 50-58.

CHERVONYUK, V.I. (2021a). Innovatsii v prave: Sovremennye yuridicheskie tekhnologii v kontekste pravovoi realnosti: Statya 1. Sovremennyi etap razvitiya innovatsii v prave [Innovations in Law: Modern Legal Technologies in the Context of Legal Reality: Article 1. The current stage of development of innovations in law]. Vestnik Moskovskogo universiteta MVD Rossii, 3, 54-57.

CHERVONYUK, V.I. (2021b). Innovatsii v prave: Sovremennye yuridicheskie tekhnologii v kontekste pravovoi realnosti: Statya 5. Tekhnologii soglasovaniya (legitimatsii soglasovannykh interesov v zakonodatelnoi deyatelnosti) [Innovations in law: modern legal technologies in the context of legal reality: Article 5. Technologies of coordination (legitimation of agreed interests in legislative activity)]. Vestnik ekonomicheskoi bezopasnosti, 2, 37-45.

FRIES, M. (2016). Man versus Machine: Using Legal Tech to Optimize the Rule of Law. SSRN Electronic Journal. https://doi.org/10.2139/ssrn.2842726

GRITSENKO, E.V., YALUNER, YU.A. (2020). Pravo na sudebnuyu zashchitu i dostup k sudu v usloviyakh informatizatsii i tsifrovizatsii: znachenie opyta stran obshchego prava dlya Rossii [The right to judicial protection and access to court in the context of informatization and digitalization: the significance of the experience of common law countries for Russia]. Sravnitelnoe konstitutsionnoe obozrenie, 3, 97-112.

IVANOVA, K.A. (2020). Pravo grazhdan na zashchitu geolokatsii i konfidentsialnost v seti Internet [Citizens' right to geolocation protection and internet privacy]. Aktualnye problemy rossiiskogo prava, 9, 32-38.

KAMIL, M. (2021). Whether to Save a Robot or a Human: On the Ethical and Legal Limits of Protections for Robotshttps. Frontiers in Robotics and AI, 8. https://doi.org/10.3389/frobt.2021.712427

KATZ, D.M., BOMMARITO, M.J., BLACKMAN, J. (2017). A general approach for predicting the behavior of the Supreme Court of the United States. Stanford: The Stanford Center for Legal Informatics.

KIRILLOVA, E.A., BLINKOV, O.E., OGNEVA, N.I., VRAZHNOV, A.S., SERGEEVA, N.V. (2020). Artificial intelligence as a new category of civil law. Journal of Advanced Research in Law and Economics, 11(1), 91-98. 
KIRILlOVA, E.A., KOVAL, V.N., ZENIN, S., PARSHIN, N.M., SHLYAPNIKOVA, O.V. (2021). Digital Right Protection Principles under Digitalization. Webology, 18(SpIs September), 910-930. https://doi.org/10.14704/WEB/V18SI04/WEB18173

KONSTANTINOV, P.D. (2020). Sudeiskoe usmotrenie, shablonnost sudebnykh reshenii i priroda pravosudiya $\mathrm{v}$ svete predikativnogo pravosudiya [Judicial discretion, stereotyped judgments and the nature of justice in the light of predicative justice]. Arbitrazhnyi i grazhdanskii protsess, 7, 27 31.

KORNEV, A.V. (2020). O nekotorykh tendentsiyakh razvitiya sistemy rossiiskogo zakonodatelstva $\mathrm{v}$ usloviyakh krizisa [On some trends in the development of the system of Russian legislation during the crisis]. Aktualnye problemy rossiiskogo prava, 6, 11-22.

LANG, P.P. (2021). Pravovye tsennosti i tsifrovye tekhnologii: problema pariteta [Legal values and digital technologies: the problem of parity]. Yuridicheskaya nauka, 2, 64-69.

MELNIK, G. (2021). Klishas: the law on traffic cameras will protect Russians from unreasonable fines. Parlamentskaya gazeta. Available from: https://www.pnp.ru/politics/klishas-zakon-odorozhnykh-kamerakh-zashhitit-rossiyan-ot-neobosnovannykh-shtrafov.html Accessed: 29 Apr. 2021.

MIROSHNICHENKO, O.I., SAFIN, N.I., KHOKHLOVA, M.S. (2019). Iskusstvennyi intellekt v professionalnoi yuridicheskoi deyatelnosti [Artificial intelligence in professional legal practice]. Baltiiskii gumanitarnyi zhurnal, 8(4(29)), 359-363.

MITIN, A.N. (2019). O protsessakh vnedreniya v yurisprudentsiyu novykh informaatsionnykh tekhnologii [On the processes of introducing new information technologies into jurisprudence]. Rossiiskoe pravo: obrazovanie, praktika, nauka, 3(111), 82-86.

PRAVKIN, S.A., SMIRNOVA, V.V. (2020). Novyi etap administrativnoi reformy v Rossii, ili chto ozhidat ot "regulyatornoi gilotiny"? [A new stage of administrative reform in Russia, or what to expect from the "regulatory guillotine"?]. Rossiiskaya yustitsiya, 7, 25-27.

Sarpekov, R.K. (2020). Tsifrovizatsiya pravovogo prostranstva [Digitalization of the legal space]. Vestnik Instituta zakonodatelstva i pravovoi informatsii Respubliki Kazakhstan, 3(61), 12-24.

RAMAZANOV, I.A., PANASENKO, S.V., CHEGLOV, V.P., KRASIL'NIKOVA, E.A., NIKISHIN, A.F. (2021). Study of innovative activity of the distributive industries of the Russian Federation in the context of the world economy digitalization and globalization. Nexo Revista Científica, 34(02), 926-941. https://doi.org/10.5377/nexo.v34i02.11620

SHULGIN, E.P. (2019). Zarubezhnyi opyt deyatelnosti organov, osushchestvlyayushchikh proizvodstvo po ugolovnym delam $\mathrm{v}$ elektronnom formate [Foreign experience of the activities of bodies carrying out criminal proceedings in electronic format]. Setevoe izdanie "Akademicheskaya mysl", 4(9), 86.

THE LAW SOCIETY. (2021). What is lawtech? Available from: https://www.lawsociety.org.uk/campaigns/lawtech/guides/what-is-lawtech Accessed: 29 Apr. 2021.

THE PROGRAM "DIGITAL ECONOMY OF THE RUSSIAN FEDERATION". (2017). Available from: http://www.consultant.ru/document/cons_doc_LAW_221756/ Accessed: 29 Apr. 2021. 
TURKIN, M.M. (2019). The mechanism of classifying intellectual property offenses as economic offenses. International Journal of Recent Technology and Engineering, 8(3), 6094-6097.

VINICHENKO, M.V., MELNICHUK, A.V., KARÁCSONY, P. (2020). Technologies of improving the university efficiency by using artificial intelligence: Motivational aspect. Entrepreneurship and Sustainability Issues, 7(4), 2696-2714.

VOLODINA, S.I., GAVRILOV, S.N. (2020). Digital transformation of the Russian legal profession. Revista Inclusiones, 7(Especial), 1-10.

ZAVYALOV, I.A., BOZIEV, T.O., BUKHAROV, N.N., SHAKHMATOV, A.V., PCHOLOVSKY, N.K. (2021). The concept of crime detection in Russian law. Cuestiones Políticas, 39(70), 598-606. https://doi.org/10.46398/cuestpol.3970.35

ZIKEEV, V. (2020). Lawmaking and "digit" (longread on the topic). Available from: https://zakon.ru/blog/2020/3/2/zakonotvorchestvo_i_cifra_longrid_na_temu Accessed: 29 Apr. 2021. 